\title{
Does the public's negative perception towards wood in rivers relate to recent impact of flooding experiencing?
}

\author{
a Institute for Environmental Sciences, University of Geneva, Switzerland \\ ${ }^{\mathrm{b}}$ Geological Survey of Spain, Spain \\ ${ }^{\mathrm{c}}$ University of Castilla-La Mancha, Spain \\ d Dpt. of Geography and Regional Planning, University of Zaragoza, Spain

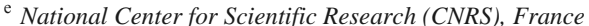 \\ ${ }^{\mathrm{f}}$ Department of Earth Sciences, University of Geneva, Switzerland \\ ${ }^{g}$ Department F.-A. Forel for Aquatic and Environmental Sciences, University of Geneva, Switzerland
}

V. Ruiz-Villanueva ${ }^{\mathrm{a}, *}$, A. Díez-Herrero ${ }^{\mathrm{b}}$, J.A. García ${ }^{\mathrm{c}}$, A. Ollero ${ }^{\mathrm{d}}$, H. Piégay ${ }^{\mathrm{e}}$, M. Stoffel ${ }^{\mathrm{a}, \mathrm{f}, \mathrm{g}}$

\section{A R T I C L E I N F O}

\section{Article history:}

Received 15 February 2018

Received in revised form 2 April 2018

Accepted 6 April 2018

Available online $\mathrm{xxx}$

Editor: D. Barcelo

Keywords:

Public perception

River management

River restoration

Instream wood

Riverscapes

\begin{abstract}
A B S T R A C T
Instream large wood (LW) is widely perceived as a source of hazard that should be avoided. This is also the case of Spain, where wood has been systematically removed from rivers for decades. Consequently, people are accustomed to rivers with minimal or no LW at all. However, the presence and transport of wood is natural and has positive ecological effects. Previous studies reported that the general negative perception towards LW in rivers is related to the lack of background knowledge about stream ecology or fluvial dynamics. However, we hypothesize here that recent flooding experience has an influence on the perception of LW as well To test this hypothesis, we surveyed groups of individuals living in different areas of Spain that have been affected more or less frequently by floods. In addition, we surveyed a group of scientists to test whether their perception towards LW differs from that of the general public. We observe that flooding experience is not the main controlling factor of how LW is perceived. Instead, we observe that respondents, independently of the time passed since the last flood, perceived watercourses with LW as less aesthetically, more dangerous, and with a larger need to improve channels than in watercourses without LW. Regional differences were detected, potentially related to differences in environmental attitudes. We confirm the existence of a gap in perception between scientific communities and the general public regarding natural river systems with wood; thereby highlighting the need to transfer knowledge, training, and education to bridge this gap. The generalized negative perception towards LW could have important consequences on the implementation of river management measures, such as LW augmentation for restoration purposes. This study underlines that wood removal should be more balanced in post-flood works and that public information is needed to implement a balanced LW management policy.
\end{abstract}

\section{Introduction}

Extensive literature exists about the positive influence of instream large wood (LW) on river ecology in particular (e.g., Gregory et al., 2003) and on fluvial dynamics in general (Gurnell, 2012; Wohl, 2013; Le Lay et al., 2013; Ruiz-Villanueva et al., 2016). The physical complexity created by instream wood (i.e., wood enhancing the creation of steps, pools, bars, channel widening and shifting, etc.) provides habitats for fish and other organisms (Benke and Wallace, 2003; Nagayama et al., 2012; Roni and Beechie, 2013; Wohl, 2017). Moreover, wood enhances sediment and organic matter storage (Gurnell et al., 2009; Wohl and Scott, 2016).

However, in many regions, LW is still perceived as a source of hazards for a variety of reasons, including navigation and flood con-

\footnotetext{
* Corresponding author.

Email address: Virginia.Ruiz@unige.ch (V. Ruiz-Villanueva)
}

trol (Sedell et al., 1991; Wohl, 2014), as wood obstructs flow and increases hydraulic resistance. Moreover, and despite the fact that instream wood usually remains relatively stable within river corridors (Rutherfurd et al., 2002), it is well known that large quantities of LW can be transported during floods. Because of these effects, LW may increase the negative consequences of floods (Diehl, 1997; Lyn et al., 2007; Mao and Comiti, 2010; Comiti et al., 2012; Ruiz-Villanueva et al., 2014; Lucía et al., 2015; Wohl et al., 2016; Steeb et al., 2017). Despite the positive ecological role of wood, landowners or public agencies are still required to remove wood from rivers in many national legislations, and without balancing pros and cons of wood conservation in river reaches. This is also the case of Spain, where the removal of LW from rivers is usually defined as "cleaning" or "clearing of rivers" (i.e., a procedure that usually includes the extraction of sediment, but also the removal of living vegetation together with dead wood).

However, now widespread recognition exists of the irreversible and negative changes that LW removal from rivers causes in river 
corridors. Clearance of LW increases sediment yields, decreases floodplain sedimentation and river complexity, decreases overbank flooding and the creation of secondary channels, which then eventually causes a fundamental, extensive, and intensive change in forested river corridors (Wohl, 2014, 2015; Wohl et al., 2016). For these reasons, wood reintroduction is increasingly used in restoration projects to improve the hydrological, morphological, and ecological status of degraded streams and rivers (Brooks et al., 2001; Reich et al., 2003; Kail et al., 2007).

In Spain, as in many other regions of Europe (Liébault and Piégay, 2002; Comiti, 2012), intensive territorial occupation over the last century has led to significant changes in rivers and streams. These changes have presumably also been favoured by the historical removal of wood accumulations from rivers (Wohl, 2014). As a result, people are nowadays accustomed to rivers with minimal or no instream wood, and when present, they may perceive it in a very negative way. In Spain, this perception seems to be enhanced after floods when people affected by catastrophic events are usually asking for severe river clearing, even if wood was reportedly not at the origin of the disaster (Correa, 2013; Ollero, 2013; Comiti et al., 2016). On the other hand, exposure and vulnerability to floods have increased across Spain due to extensive urbanisation in flood-prone areas, and also potentially as a result of climate change. Consequently, river and flood risk management should regulate LW in rivers by balancing the good ecological status of the fluvial ecosystem and the potential hazards during floods. Recently, the European Water Framework (2000/60/EC) and the related Flood Directive (2007/60/EC) provided a legal framework to favour good ecological and geomorphic conditions of watercourses, which may in fact have implications for current LW management in rivers.

The perception of riverscapes by people should be one important aspect to be considered in river management, however, unless in forest planning decisions, in which aesthetic values are regularly considered (Ribe, 2006; Palmer, 2008; Ribe, 2009), landscape assessments applied to rivers are at an even earlier developmental stage (Pflüge et al., 2010). It is recognised that environmental projects are more acceptable if they contain a management design consistent with the population's perception (Higgs, 1997; Vining et al., 2000; Miller and Hobbs, 2007). In the case of perception towards instream wood in riverscapes, the extent to which individuals recognize that wood is beneficial in rivers depends on different socio-cultural aspects (Piégay et al., 2005; Mutz et al., 2006; Chin et al., 2008, 2014; Le Lay et al., 2008; Wyzga et al., 2009). First surveys on the perception of wood were realized with students from several countries in 2005, and revealed the need for education on what constitutes a natural river in a forested context (Piégay et al., 2005). The same survey, based on riverscapes scenes with and without wood, has later been used around the World and with different target populations. We review these studies and available literature about instream wood perception and summarize the key findings in Table 1 (other landscape perception studies are out the scope of our work). Interestingly, students from China, India, and Russia perceived LW as unnatural elements in rivers (Le Lay et al., 2008). On the other hand, in regions with abundant forests and active research on aquatic ecosystems and wood functions, such as Germany, interviewed students had a more positive attitude towards wood (Mutz et al., 2006). However, differences persist and likely depend on the background of surveyed people (Wyzga et al., 2009) or their familiarity with the environment (Le Lay et al., 2008).

People evaluate landscapes and environments in terms of how they meet psychological, social, and/or physical needs (Brown and Daniel, 1984; Daniel and Boster, 1976; Rosenberger and Smith,
1998; Bechtel and Churchman, 2002), and perception is highly dependent upon the experiential context of the place being evaluated (Carlson, 1977; Zube and Pitt, 1981; Stokols, 1995; Wapner and Demick, 2002). Following this reasoning, we hypothesize that the perception of wood in rivers in Spain is not only influenced by the knowledge and information on the significance of wood in stream systems (Wyzga et al., 2009; Le Lay et al., 2008), but also by the experiencing of recent floods. Due to the generalized idea that negative consequences of floods are enhanced by the presence of wood in rivers - while ignoring any positive effects - we present a follow-up of the perception study published by Piégay et al. (2005) to test this hypothesis. The aim of this work is to evaluate whether people living in areas that have been affected recently by floods have a different perception towards instream wood than people living in areas that have not been affected by floods and who are therefore lacking recent flood experience. Our target people are therefore divided in controlled groups of individuals living in different mountain areas which were recently (i.e. 2012, 2013) affected by floods. In addition, we surveyed a group of people with linkages to the scientific community (e.g., universities, research institutes, water authorities). This allowed us to test whether the perception of instream wood of scientists is different from the perception towards instream wood of the general public.

As we analysed different groups of people with different backgrounds, ages, and knowledge of rivers, we investigated potential subgroups (or clusters within previous groups) underlying different socio-demographic and cultural factors. Moreover, we analysed their opinion regarding river management in general.

\section{Material and methods}

\subsection{Data collection}

\subsubsection{The questionnaire}

Perception of wood was assessed using a questionnaire based on visual perception of 20 colour photographs of riverscapes (ten scenes with and ten without wood). This questionnaire was designed in previous studies, and we refer to the original study (Piégay et al., 2005) and Supplementary material of this study (Questionnaire and Fig. S1) for further details. The selection of pictures and the design of the questionnaire are explained in the previously published papers, so we do not repeat this information here. We used the same scenes and questions, translated the documentation to Spanish and complemented the questionnaire by adding an additional question at the end of the survey about river management (see below).

The questionnaire was distributed either online or in person. By doing so, we did not inform participants that the survey focused on wood perception. Instead, participants thought that the aim of the survey was simply to evaluate the riverscapes. The surveyed persons were asked to rank each riverscape scene from 0 (lowest) to 10 (highest), using a scalar grading according to aesthetics, naturalness, danger, and any possible need for improvement (referred to river training or management). Danger and need for improvement were further analysed with two additional questions, namely the type of perceived danger and the type of improvement. Respondents could select the type of perceived danger according to different modalities: no danger, flooding or inundation, danger because of bank erosion, danger to practice leisure activities, degraded water quality, or other danger. The type of improvement could be also selected among several modalities: no improvement, improvement of scenic beauty, improvement of habitats for fauna, bank stabilization, channel cleaning, engineering measures for flooding risk mitigation, other. 
Table 1

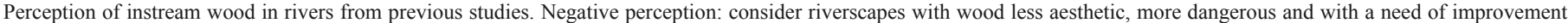
Positive perception: consider riverscapes with wood more aesthetic, less dangerous and no need for improvement.

\begin{tabular}{|c|c|c|c|c|c|c|}
\hline \multirow[t]{3}{*}{ Source } & \multirow{3}{*}{$\begin{array}{l}\text { Surveyed people (sample) } \\
\text { Areas and social groups } \\
\text { Territories }\end{array}$} & \multicolumn{4}{|l|}{ Perception results } & \multirow[t]{3}{*}{ Main conclusions } \\
\hline & & \multicolumn{2}{|c|}{ Differences according to geographical areas } & \multicolumn{2}{|c|}{ Differences according to social groups } & \\
\hline & & Negative & Positive & Negative & Positive & \\
\hline $\begin{array}{l}\text { Piégay et } \\
\text { al. } \\
(2005)\end{array}$ & $\begin{array}{l}\text { Undergraduate students } \\
(1886) \text {. } \\
10 \text { disciplines } \times 4 \text { study } \\
\text { groups. } \\
8 \text { countries and } 2 \text { states of } \\
\text { USA. }\end{array}$ & $\begin{array}{l}\text { France, India, Italy, } \\
\text { Poland, Russia, Spain } \\
\text { and Texas (USA) }\end{array}$ & $\begin{array}{l}\text { Germany, Sweden and Oregon } \\
\text { (USA) }\end{array}$ & - & $\begin{array}{l}\text { No significant } \\
\text { differences } \\
\text { according to } \\
\text { scientific } \\
\text { discipline }\end{array}$ & $\begin{array}{l}\text { Cultural background } \\
\text { is driving the way of } \\
\text { thinking, irrespective } \\
\text { of the disciplinary } \\
\text { background. }\end{array}$ \\
\hline $\begin{array}{l}\text { Mutz et } \\
\text { al. } \\
(2006)\end{array}$ & $\begin{array}{l}\text { Undergraduate students } \\
(365) . \\
\text { Six bachelor disciplines. } \\
\text { Germany. }\end{array}$ & - & - & $\begin{array}{l}\text { BSc. discipline } \\
\text { related with } \\
\text { social sciences }\end{array}$ & $\begin{array}{l}\text { Five disciplines } \\
\text { BSc. related with } \\
\text { Water } \\
\text { Management. }\end{array}$ & $\begin{array}{l}\text { General acceptance } \\
\text { for the reintroduction } \\
\text { of wood in stream } \\
\text { rehabilitation and } \\
\text { restoration }\end{array}$ \\
\hline $\begin{array}{l}\text { Chin et } \\
\text { al. } \\
\text { (2008) }\end{array}$ & $\begin{array}{l}\text { Undergraduate students } \\
(376) \text {. } \\
\text { Geography/environmental } \\
\text { science. } \\
8 \text { states of USA. }\end{array}$ & Most respondents & Oregon ( 2 campus) (USA) & - & $\begin{array}{l}\text { High } \\
\text { environmental } \\
\text { consciousness. } \\
\text { Sharp public } \\
\text { awareness of } \\
\text { endangered } \\
\text { species (e.g. } \\
\text { salmon). }\end{array}$ & $\begin{array}{l}\text { In general channels } \\
\text { containing wood are } \\
\text { perceived as } \\
\text { unaesthetic, } \\
\text { hazardous, and } \\
\text { needing cleaning } \\
\text { permeate, except by } \\
\text { students in Oregon } \\
\text { (probably influenced } \\
\text { by high } \\
\text { environmental } \\
\text { expectations). } \\
\text { Invalidate hypothesis } \\
\text { of environmental } \\
\text { familiarity as attitude } \\
\text { driver }\end{array}$ \\
\hline $\begin{array}{l}\text { Le Lay et } \\
\text { al. } \\
(2008)\end{array}$ & $\begin{array}{l}\text { Undergraduate students } \\
(2250) \text {. } \\
\text { Four distinct disciplines. } \\
9 \text { countries and } 2 \text { states of } \\
\text { USA. }\end{array}$ & China, Russia and India & $\begin{array}{l}\text { Germany, Sweden and Oregon } \\
\text { (USA) }\end{array}$ & - & & $\begin{array}{l}\text { Three main attitudes } \\
\text { towards wood are } \\
\text { identified. } \\
\text { Positive attitude } \\
\text { towards wood is } \\
\text { shown by } \\
\text { respondents requiring } \\
\text { improvement of } \\
\text { strongly altered } \\
\text { riverscapes } \\
\text { confirming } \\
\text { environmental } \\
\text { consciousness as a } \\
\text { critical driver }\end{array}$ \\
\hline $\begin{array}{l}\text { Wyzga et } \\
\text { al. } \\
(2009)\end{array}$ & $\begin{array}{l}\text { Undergraduate students, } \\
\text { Water and National Park } \\
\text { managers (472). } \\
3 \text { BSc. disciplines } \times 2 \\
\text { levels. } \\
\text { Poland. }\end{array}$ & - & & $\begin{array}{l}\text { Beginning } \\
\text { undergraduate } \\
\text { students (fist- } \\
\text { year). Water } \\
\text { engineering } \\
\text { students and } \\
\text { Water Authority } \\
\text { managers. }\end{array}$ & $\begin{array}{l}\text { Advanced } \\
\text { undergraduate } \\
\text { students (third- } \\
\text { and fourth-years). } \\
\text { Geography and } \\
\text { Biology students. } \\
\text { National Park } \\
\text { managers. }\end{array}$ & $\begin{array}{l}\text { The negative } \\
\text { perception of rivers } \\
\text { with wood can be } \\
\text { significantly } \\
\text { modified in the } \\
\text { course of academic } \\
\text { education }\end{array}$ \\
\hline $\begin{array}{l}\text { Chin et } \\
\text { al. } \\
\text { (2012) }\end{array}$ & $\begin{array}{l}\text { River managers (196). } \\
7 \text { states of USA. }\end{array}$ & - & Oregon (USA) & - & $\begin{array}{l}\text { Experienced } \\
\text { managers. }\end{array}$ & $\begin{array}{l}\text { American managers } \\
\text { (across different } \\
\text { disciplines: } \\
\text { conservation, } \\
\text { fisheries, forestry, } \\
\text { recreation and water), } \\
\text { perceive rivers with } \\
\text { wood as more } \\
\text { aesthetically } \\
\text { pleasing, less } \\
\text { dangerous and } \\
\text { needing less } \\
\text { improvement }\end{array}$ \\
\hline
\end{tabular}


In addition to the perception of the stream or river scenes, we requested additional information about the personal opinion of participants with respect to river management (see Supplementary material). Participants also had to state whether they agree or disagree with the following sentences:

- River management interventions reduce flood risk in the surrounding area

- River management should be focused on streambed clearance and bank stabilization

- River management should be focused on landscape and ecosystem enhancement

- We should let nature do without river interventions

Background information about education (based on the following classes: civil/hydraulic engineering, geography/environmental sciences, ecology/biology, literature/arts/law or other), personal residence (in urban or rural areas, and the proximity to a watercourse), frequency and reason of visits to a watercourse, gender, and age were also requested from each respondent.

Our target respondents were on the one hand adults and permanent residents living in areas that were recently affected by floods, and on the other hand representatives from the larger scientific community. In the first case, we visited different mountain regions where floods occurred recently (see Section 2.3 for details) and distributed the questionnaire in person. In the case of the scientific community, we distributed the questionnaire online.

Table S1 in the Supplementary material provides more details, summarizes the objectives, sources of data, and analytic methodologies applied in this work and compares them with previous works on the perception of instream wood.

\subsubsection{The online survey}

The online survey was uploaded and spread out using the open source platform LimeSurvey (www.limesurvey.org). The online survey was distributed among people related to the scientific community (this group is called "scientists" from now on). This group included university students, researchers and professors, technicians, and management specialists in flood risk analysis. Access to the online questionnaire was distributed among researchers and professors from several universities who then asked their students and colleagues to answer it. Since the questionnaire was anonymous it was not possible to directly track the exact location of the respondents, but in general, most of the respondents of this group lived in large, urbanized areas located all around the Iberian Peninsula. The online survey was available between January 2014 and August 2014, it was started by 441 people, but it was only completed by 135 , leaving 306 incomplete responses.

\subsubsection{The field survey and study sites}

During summer 2014 and winter 2016, we visited sites that were more or less recently affected by floods and distributed the questionnaire in person among the population:

- Four surveys were conducted in the Pyrenees (Fig. 1), 3 of them in 2014: (i) Canfranc Valley, at Villanúa and Castiello $\left(155 \mathrm{~km}^{2}\right.$ basin, with $34 \%$ forest cover), i.e. at the sites most affected by the October 2012 flash flood (with a flood return period between 50 and 100 years), (ii) Benasque Valley, affected by the June 2013 flash flood (with an estimated return period located again somewhere between 50 and 100 years), at Benasque $\left(184 \mathrm{~km}^{2}\right.$ basin, with $22 \%$ forest cover) and Castejón towns, and (iii) Arán Valley, also affected by the June 2013 flash flood (50-100years flood), at Vielha town $\left(245 \mathrm{~km}^{2}\right.$, with $36 \%$ forest cover). These are three sparsely populated areas $(1250,2000$, and 5600 permanent inhabitants, respectively); however, its main economic activity is tourism and the population increase due to the effect of seasonality (to a maximum of $20,000,14,000$, and 19,000 persons during peak season, respectively).

- Also, in the Pyrenees, we surveyed a group of people living in the town of Sabiñánigo in 2016 (Fig. 1), near the other towns and with similar topographical and land use characteristics, although less touristic; this small city has 9000 permanent inhabitants and floods did not occur in the last 50 years.

- Near the Pyrenees, in the middle Ebro River basin we distributed the questionnaire among people living in Pradilla de Ebro (Fig. 1), a village of 600 inhabitants $\left(30,000 \mathrm{~km}^{2}\right.$ river basin area), where damage to agriculture commonly occurs as a result of frequent floods, with the most recent event in March 2013 (return period 5 years). In each of these populations, 30 questionnaires were completed (150 in total).

- In the Spanish Central System (Fig. 1), two surveys were carried out in 2014 and 2016. Firstly, we distributed the questionnaire among a group of inhabitants of the village of Navaluenga (Central Spain), which is frequently affected by floods of the Alberche River (drainage area of $698 \mathrm{~km}^{2}, 30 \%$ forested), with the latter

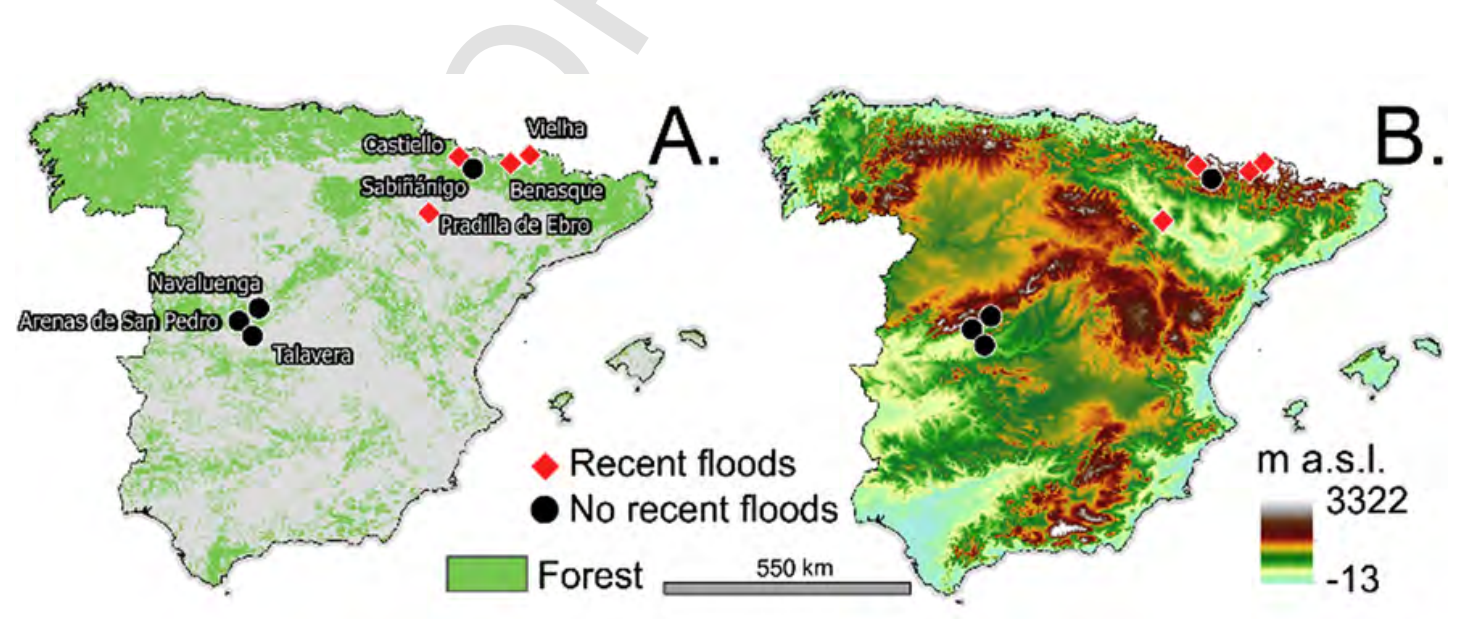

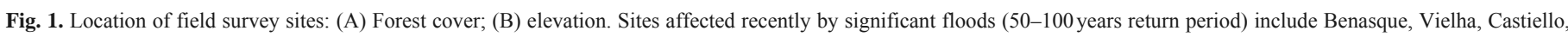

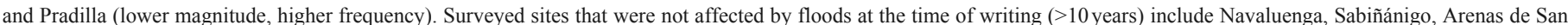
Pedro, and Talavera. 
causing extensive damage to infrastructure in those areas of the village located close to the river. The most important flood before the survey occurred in December 2000 with an estimated return period of between 2 and 5 years. In 2012, the Water Authorities carried out intensive tree cutting along the river and a removal of wood. Navaluenga is sparsely populated (2000 permanent inhabitants), but during summer its population increases up to 15,000 persons. A total of 70 questionnaires were distributed in Navaluenga, of which 44 were completed.

- The second survey was carried out in 2016 in the village of Arenas de San Pedro (Fig. 1; 6900 inhabitants) on the banks of the Arenal River $\left(67 \mathrm{~km}^{2}\right.$ drainage area; $54 \%$ forested), also in the Spanish Central System, in the Gredos Mountain Range. Although the Arenal catchment area is frequently affected by heavy rains, no significant flood damage occurred in the last 10 years. However, in 2012, the Water Authorities clear cut several trees from the riparian zone. A total of 31 questionnaires were filled in this village.

- The last surveyed site was Talavera de la Reina (Fig. 1; 84,119 inhabitants, Toledo, Castilla La Mancha). Some 28 questionnaires were filled in this town. The Tagus River crosses the city of Talavera $\left(34,319 \mathrm{~km}^{2}\right.$ drainage area, from $10 \%$ is forested and $71 \%$ is covered by agriculture and pastures; SIGPAC, 2014), which has been causing flood damage in the past. The most important event occurred in 1947, whereas in recent years, the city has not been affected by floods. The river flow regime is heavily altered by regulation infrastructures, consumption from the Madrid metropolitan area, and drawdowns for agricultural uses. These factors result in extremely low average flow in July (below $2 \mathrm{~m}^{3} / \mathrm{s}$ in some years), featuring quality problems and a degradation of the river.

\subsection{Data analysis}

Results of the questionnaires were analysed statistically using R, SPSS, and Latent Gold software. For each feature evaluated, respondent's scores of all scenes were averaged and used to calculate statistical characteristics for a given group of respondents. In case that average scores did not follow a normal distribution, statistical differences in the distributions were tested by the non-parametric Wilcoxon-Mann-Whitney signed rank and the Kruskal-Wallis tests. Correlation between scores given to the analysed aspects (aesthetics, naturalness, danger and improvement) was tested with the Spearman correlation test.

Research questions regarding possible clusters were tested with a latent class cluster analysis (LCCA; Vermunt and Magidson, 2002; Vermunt, 2003; Díez-Herrero et al., 2015; Bodoque et al., 2016). LCCA is a model-based probabilistic clustering approach used to define different sub-populations within a larger population. An important difference between standard cluster analysis techniques and LC clustering is that the latter is a model-based probabilistic clustering approach. This means that a statistical model is postulated for the population from which the sample under study is coming. Although each object is assumed to belong to one class or cluster, we take account of uncertainties about an object's class membership. This makes LCCA conceptually similar to fuzzy clustering techniques. However, in fuzzy clustering, object's grades of membership are the parameters to be estimated (Kaufman and Rousseeuw, 1990) while in LCCA, individual's posterior class-membership probabilities are computed from the estimated model parameters and its observed scores. This makes it possible to classify other objects belonging to the population from which the sample is taken, which is not possible with standard fuzzy cluster techniques.
The LCCA model used a series of indicators: (i) aesthetic riverscapes with and without wood (2 variables); (ii) naturalness riverscapes with and without wood (2 variables); (iii) threat riverscapes with and without wood ( 2 variables); (iv) need to improve riverscapes with and without wood ( 2 variables); and relevant covariates: (i) area of residence (urban/rural); (ii) contact with rivers (survey site, living close to rivers, frequency of visit, purpose of visit); (iii) gender; (iv) age; and (v) education.

In addition, when clusters were identified, we analysed the personal opinion regarding type of dangers perceived and the river improvements required. We used non-parametric Kruskal-Wallis and Pearson Chi-Square tests to see whether an individual belonging to a specific cluster perceived a specific danger and preferred a specific management approach and a type of river/stream improvement.

\section{Results}

A total of 720 questionnaires were distributed (online and in person), of which 388 were completed and therefore used for analysis. Table 2 summarizes the demographic characteristics of all respondents.

\subsection{Perception of wood in riverscapes}

The rates of each scene revealed differences in the perception of the different environments shown in the pictures, not only towards the presence of instream wood (Fig. 2), but also towards the degree of human interventions (e.g. Scene F was generally rated with very low values in all sites), the size of sediment (e.g. different rates to images $\mathrm{P}$ and R) or the turbulence of the flow (e.g. images Q and M). As these issues were not the main objective of our study we do not analyse them in detail here and instead provide results in the Supplementary material (Figs. S2-S5).

Regarding perception towards the presence of wood in riverscapes, we found significant differences related to aesthetics, naturalness, degree of danger, and need for improvements (Fig. 2) in all cases.

Regarding aesthetics, scores were generally higher in the pictures without wood (median $=8$, mean $=6.9, \mathrm{SD}=2.8$ ) than with wood (median $=6$, mean $=5.75, \mathrm{SD}=3$ ). Regarding naturalness, images with wood were scored with slightly higher rates (with wood: median $=8$, mean $=7.33, \mathrm{SD}=2.37$; without wood: median $=8$, mean $=6.81$, $\mathrm{SD}=2.94)$. The pictures without wood were rated with lower levels of danger (without wood: median $=4$, mean $=3.98, \mathrm{SD}=2.99$; with wood: median $=5$, mean $=5.06, \mathrm{SD}=3.08$ ). Finally, pictures with wood were also rated with higher needs for improvements than riverscapes without wood (with wood: median $=6$, mean $=5.49, \mathrm{SD}=3.27$; without wood: median $=2$, mean $=3.35, \mathrm{SD}=3.11$ ).

Fig. 3 shows that scores were significantly different for river scenes with and without wood within the two groups (i.e., people living in places recently affected by floods and not affected by recent floods). In all cases, river scenes with wood were rated as less aesthetical, more dangerous, and with a larger need for improvements. Naturalness was very similar in river scenes with and without wood. Scores given to scenes without wood were not significantly different between respondents living in areas that were (not) recently affected by floods, except when it comes to the need for improvement. Respondents living in areas that were not recently affected by floods ranked scenes without wood with higher needs for improvements. On the contrary, we found no significant differences in the score distributions given to scenes with wood regarding the need for improvement 
Table 2

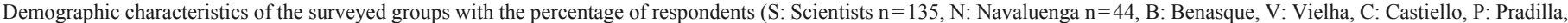
Sa: Sabiñánigo $n=30$ each site, A: Arenas $n=31$, T: Talavera $n=28$, total number $n=388$ ).

\begin{tabular}{|c|c|c|c|c|c|c|c|c|c|}
\hline & $\mathrm{S}$ & $\mathrm{N}$ & $\mathrm{B}^{\mathrm{a}}$ & $\mathrm{V}^{\mathrm{a}}$ & $\mathrm{C}^{\mathrm{a}}$ & $\mathrm{P}^{\mathrm{a}}$ & $\mathrm{Sa}$ & A & $\mathrm{T}$ \\
\hline $\begin{array}{l}\mathrm{N}^{\circ} \text { of usable questionnaires } \\
\text { Usual living place (percentage of re }\end{array}$ & 135 & 45 & 30 & 29 & 30 & 30 & 30 & 31 & 28 \\
\hline Rural area & 10 & 14 & 37 & 50 & 13 & 50 & 33 & 71 & 7 \\
\hline Urban area & 48 & 39 & 50 & 37 & 60 & 47 & 27 & 6 & 61 \\
\hline $\begin{array}{l}\text { Between } \\
\text { Live close to a river or a stream (per }\end{array}$ & 42 & 48 & 13 & 13 & 27 & 3 & 40 & 23 & 32 \\
\hline Yes & 62 & 60 & 83 & 90 & 93 & 97 & 100 & 97 & 89 \\
\hline No & 38 & 40 & 17 & 10 & 7 & 3 & 0 & 3 & 11 \\
\hline \multicolumn{10}{|c|}{ Frequency visiting rivers or streams (percentage of respondents) } \\
\hline$<1$ times a year & 1 & 2 & 20 & 20 & 13 & 0 & 3 & 3 & 11 \\
\hline 1 to 5 times a year & 20 & 18 & 40 & 30 & 17 & 20 & 23 & 6 & 29 \\
\hline 6 to 20 times a year & 20 & 14 & 7 & 20 & 7 & 27 & 23 & 26 & 21 \\
\hline$>20$ times & 58 & 66 & 33 & 30 & 63 & 53 & 50 & 65 & 39 \\
\hline \multicolumn{10}{|c|}{ Reason to visit rivers or streams (percentage of respondents) } \\
\hline Professional/Training & 44 & 73 & 20 & 3 & 7 & 3 & 0 & 3 & 0 \\
\hline Leisure activity & 56 & 27 & 80 & 97 & 93 & 97 & 100 & 97 & 100 \\
\hline \multicolumn{10}{|l|}{ Gender (percentage of respondents) } \\
\hline Female & 36 & 57 & 67 & 47 & 50 & 53 & 53 & 52 & 50 \\
\hline Male & 64 & 43 & 33 & 53 & 50 & 47 & 47 & 48 & 50 \\
\hline \multicolumn{10}{|l|}{ Age (percentage of respondents) } \\
\hline$<20$ & 0 & 3 & 3 & 0 & 3 & 0 & 7 & 0 & 7 \\
\hline $20-29$ & 20 & 20 & 20 & 7 & 30 & 10 & 10 & 6 & 0 \\
\hline $30-39$ & 40 & 30 & 30 & 27 & 17 & 17 & 17 & 16 & 39 \\
\hline $40-49$ & 23 & 17 & 17 & 33 & 13 & 30 & 23 & 29 & 46 \\
\hline $50-59$ & 16 & 17 & 17 & 10 & 23 & 20 & 23 & 29 & 0 \\
\hline$>59$ & 1 & 13 & 13 & 23 & 13 & 23 & 20 & 19 & 7 \\
\hline \multicolumn{10}{|c|}{ Level of studies (percentage of respondents) } \\
\hline Undergraduate & 8 & 80 & 77 & 67 & 60 & 87 & 50 & 61 & 57 \\
\hline Postgraduate & 92 & 20 & 23 & 33 & 40 & 13 & 50 & 39 & 43 \\
\hline \multicolumn{10}{|c|}{ Background (percentage of respondents) } \\
\hline Civil/hydraulic engineering & 36 & 77 & 0 & 10 & 0 & 7 & 10 & 8 & 0 \\
\hline Geography/environmental sciences & 30 & 2 & 0 & 0 & 0 & 0 & 7 & 0 & 0 \\
\hline Ecology/biology & 16 & 0 & 0 & 0 & 0 & 0 & 0 & 17 & 0 \\
\hline Literature/arts/laws & 4 & 0 & 10 & 3 & 7 & 3 & 0 & 25 & 8 \\
\hline Other & 7 & 7 & 0 & 0 & 3 & 0 & 33 & 50 & 58 \\
\hline Not displayed & 8 & 14 & 90 & 87 & 90 & 90 & 0 & 0 & 33 \\
\hline
\end{tabular}

${ }^{a}$ Sites recently affected by floods.

between the respondents living in areas that were (not) recently affected by floods. The distributions of scores given to scenes with wood regarding aesthetics and danger were again significantly different between the two groups of respondents. Respondents living in areas recently affected by floods rated riverscapes with wood as more aesthetic, but more dangerous than respondents living in areas that were not recently affected by floods. Further analysis of the scores given by the respondents from different sites to riverscapes with and without wood showed that in fact respondents from sites that were recently affected by floods rated the riverscapes with wood as less aesthetic, less natural, and with similar need for improvements (Fig. 4) than respondents from sites not recently affected by floods. The presence of wood in the river scenes was perceived as significantly more dangerous by respondents from sites affected by recent floods, with the highest scores given by respondents from Pradilla (Figs. 3 and 4).

Fig. 4 also shows differences between respondents from sites located in the Pyrenees and Northern Spain (i.e., Pradilla) as compared to respondents from Central Spain, revealing that a geographical pattern may exist. Among the respondents from sites that were not recently affected by floods, respondents from Sabinánigo (located in the Pyrenees) rated riverscapes with wood with higher scores in terms of aesthetics, naturalness, and lower degree of danger than respondents from Arenas de San Pedro, Navaluenga, and Talavera (all located in Central Spain). Another observation from these results is related to scores given by respondents from Pradilla in relation to the degree of danger and need for improvements, which were the highest despite the fact that the recent flood affecting the site was only a 5 -year return period flood as compared to the recent events in Benasque, Castiello, and Vielha (where all events were 50-100-year floods).

Fig. 4 exposes that the groups of scientists (i.e., online respondents) showed a different perception of riverscapes with wood as compared to the general public. In general, scientists considered riverscapes with wood as being more aesthetic and more natural than riverscapes without wood (Fig. 5), although in some cases, differences were not significant (e.g. naturalness). Regarding danger, scientists did not make a difference between riverscapes with and without wood, and they rated scenes with wood with a lower degree of danger than the general public.

In most cases, we did not find statistically significant differences between the scores given by scientists to scenes with and without wood. The only difference exists regarding naturalness and the need for improvements, for which scientists perceived scenes with wood as significantly more natural and with more needs for improvements. On the contrary, the general public perceived scenes with wood significantly different than scenes without wood (except for naturalness), less aesthetic, more dangerous and with more needs for improvements.

Responses by all groups showed significant positive correlations between aesthetics and naturalness as well as between danger and the need for improvement (Table 3), independently from the presence of wood in the images. We observe significant negative correlations be- 
Aesthetics

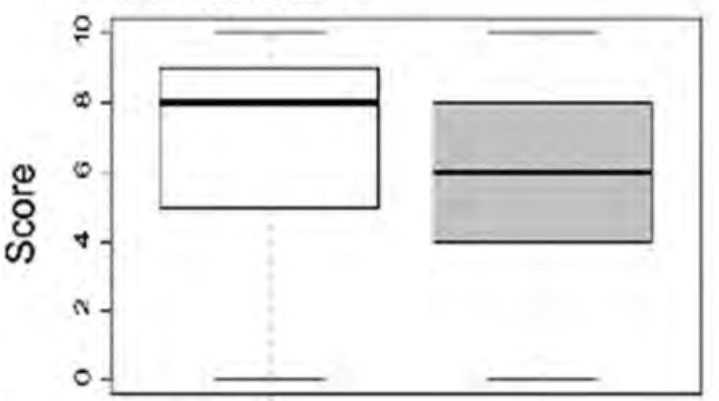

Danger

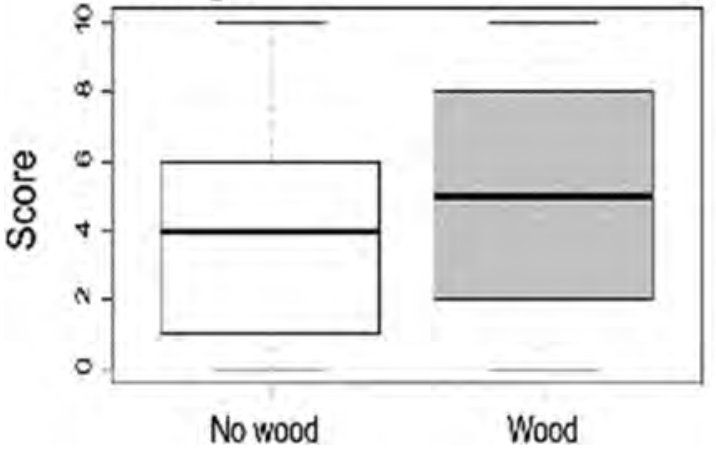

Naturalness

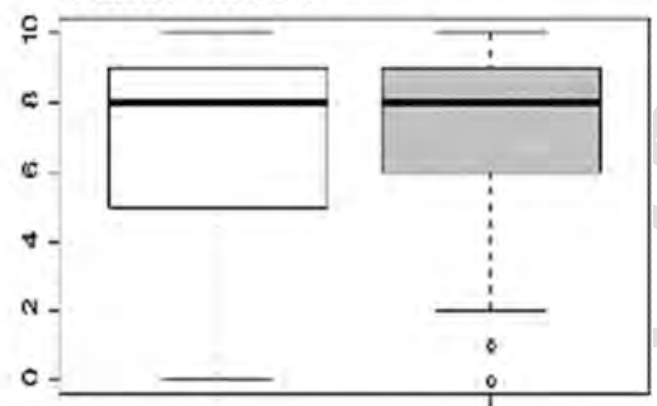

Need for improvements

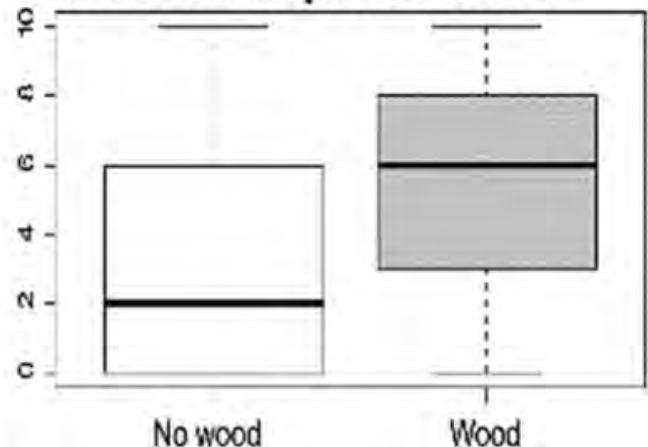

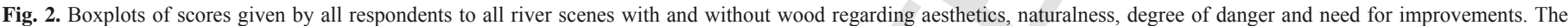

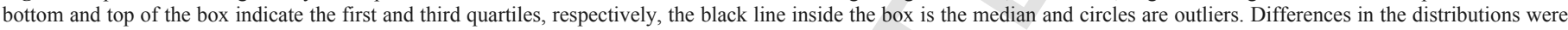
statistically significant (Wilcoxon-Mann-Whitney test $p$-value $<0.05$ ) in all cases.
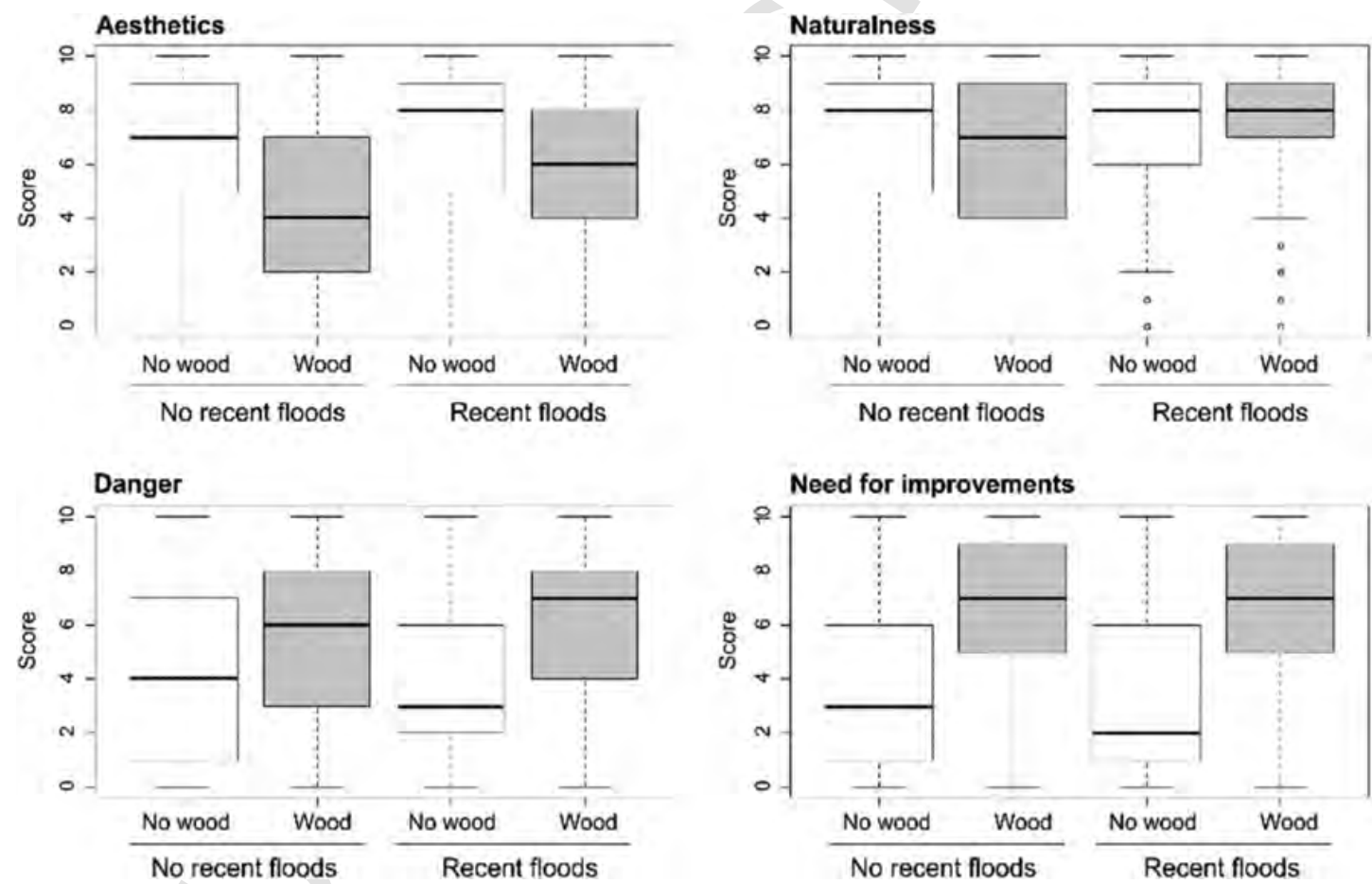

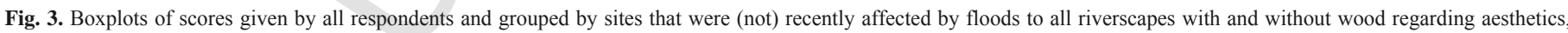

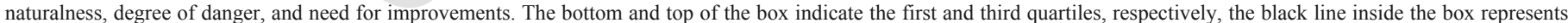
median values, and circles are outliers. 

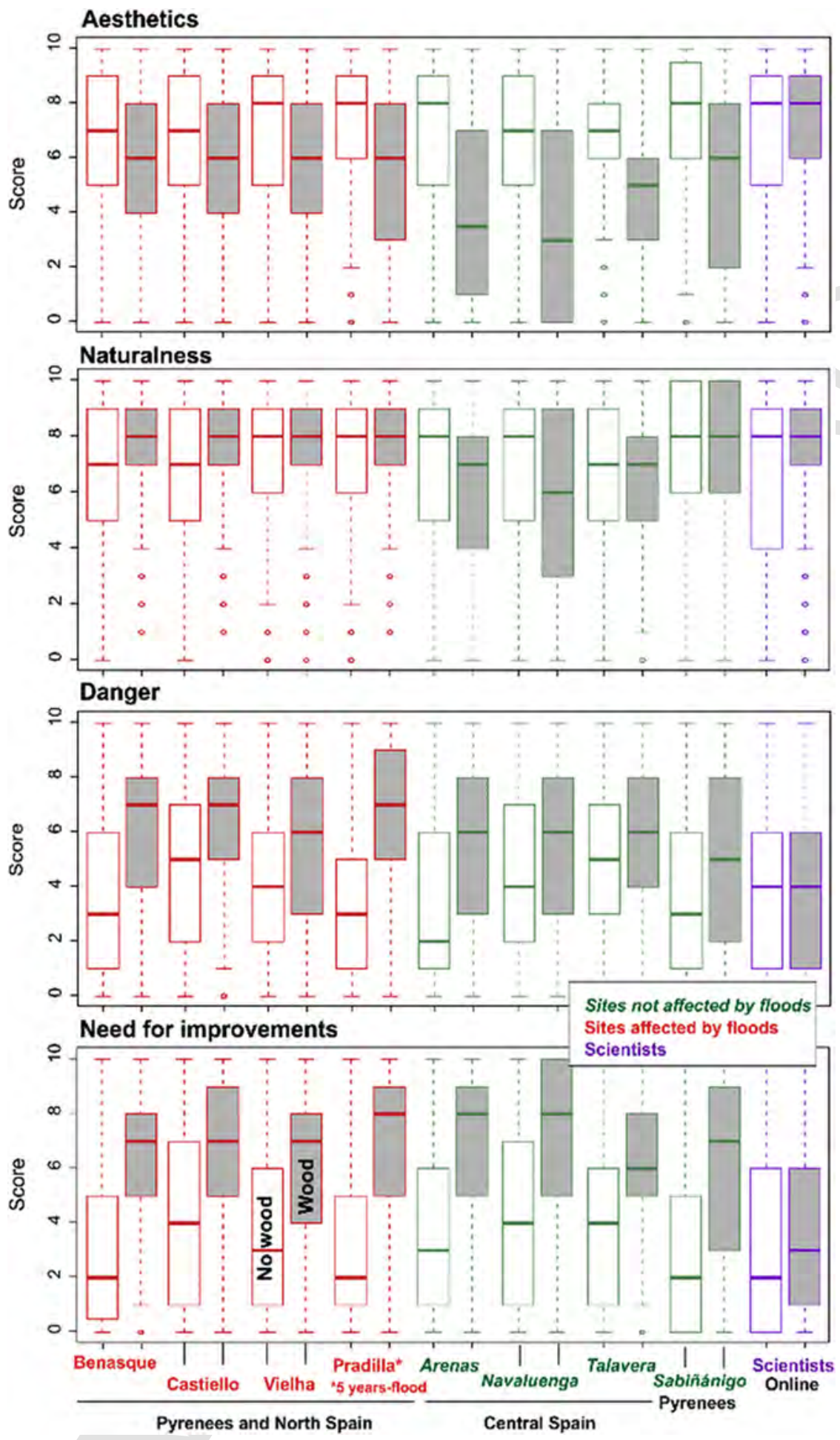

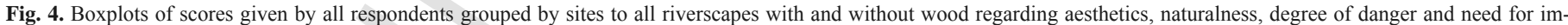
provements. The bottom and top of the box indicate the first and third quartiles, respectively, the line inside the box is the median and circles are outliers.

tween aesthetics and need for improvement, and between naturalness and need for improvement (Table 3).

In the case of riverscapes considered more dangerous, respondents claimed a high need for improvement, focused on river cleaning due to an association between flood risk and the presence of wood (Fig. 6).
More than $80 \%$ of respondents from the field surveys, independently from the time since a flood occurred, agreed that river management interventions reduce flood risk, whereas $>40 \%$ of the scientists disagreed with this affirmation. A vast majority $(>80 \%)$ of the general public agreed with the affirmation that the focus of river management should be on streambed clearance and bank stabiliza- 

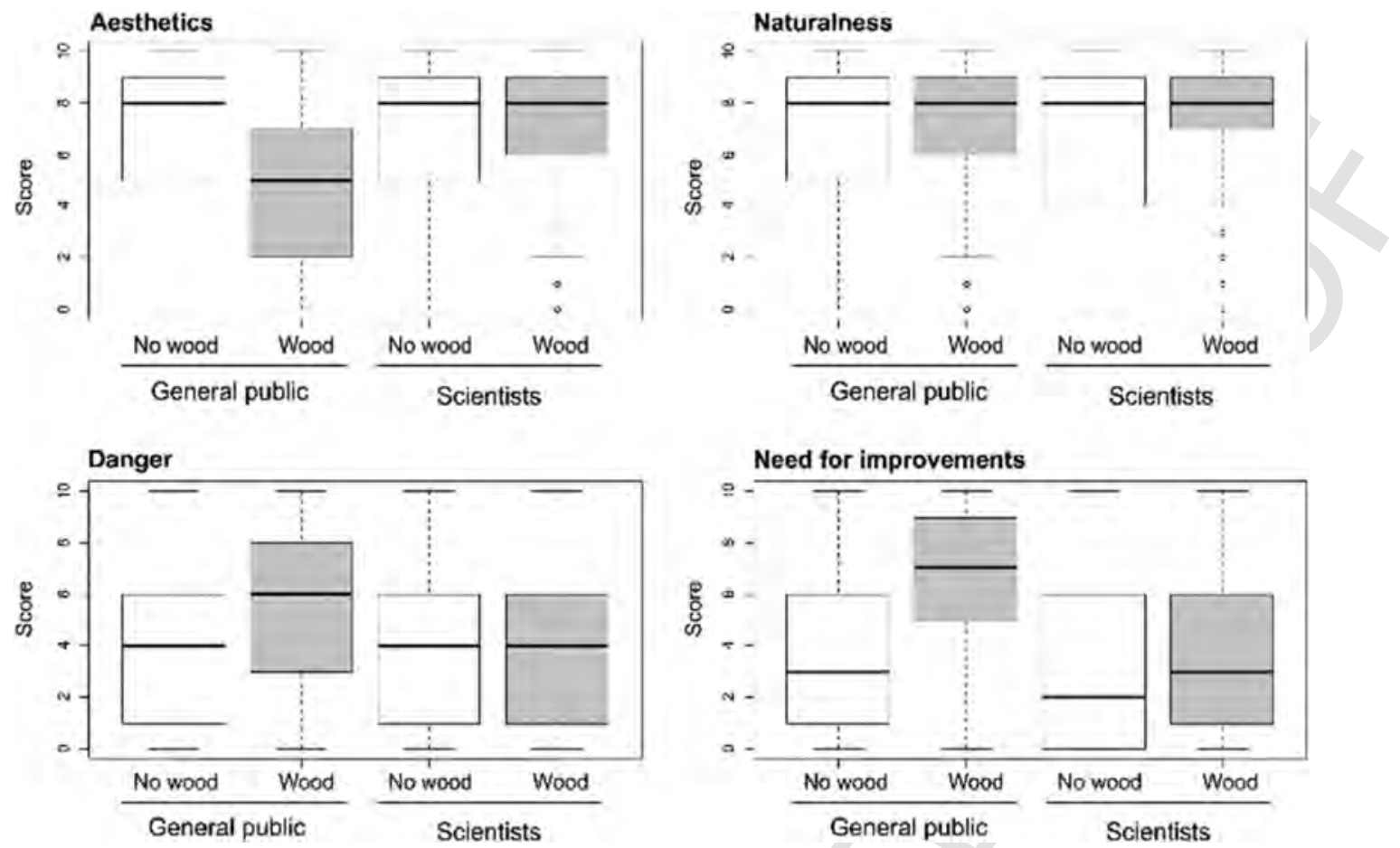

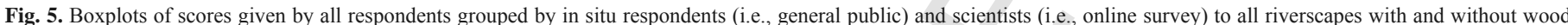

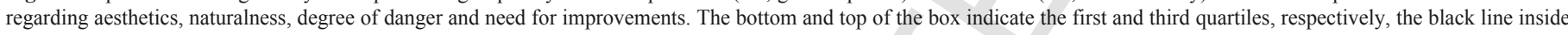
the box is the median and circles are outliers.

Table 3

Correlation matrix (Spearman coefficients) for the response variables (aesthetics, naturalness, danger and need for improvement). All are significant correlations with $p<0.05$. Correlation tests for scientists and the general public yielded similar results (Tables S10 and $\mathrm{S} 11$ ).

\begin{tabular}{lllll}
\hline & Aesthetics & Improvements & Naturalness & Danger \\
\hline Images with wood & & & & \\
Aesthetics & 1.00 & -0.52 & 0.57 & -0.30 \\
Improvements & & 1.00 & -0.24 & 0.57 \\
Naturalness & & 1.00 & -0.11 \\
$\begin{array}{llll}\text { Danger } \\
\text { Images without wood }\end{array}$ & & & 1.00 \\
Aesthetics & 1.00 & -0.51 & & -0.12 \\
Improvements & 1.00 & 0.79 & 0.39 \\
Naturalness & & & -0.47 & -0.09 \\
Danger & & & 1.00 & 1.00 \\
\hline
\end{tabular}

tion, although around $50 \%$ of the scientists disagreed. The opinion that river management should focus on landscape and ecosystem enhancement was well spread among all respondents - only in Pradilla the opinion was slightly different with $>50 \%$ of all respondents disagreeing. Finally, the idea that nature should be left natural and without river interventions was not well received, except within the scientific community where about $50 \%$ agreed with this suggestion (see Table $\mathrm{S} 7$ for details). These opinions were further analysed based on LCCA.

\subsection{Cultural and social river perception contrasts and influence of frequency of floods}

We identified contrasting perceptions of rivers and streams with and without wood among all respondents that are not only explained by the recent occurrence of floods, but that may also be influenced by other demographic aspects. To better understand this influence, we
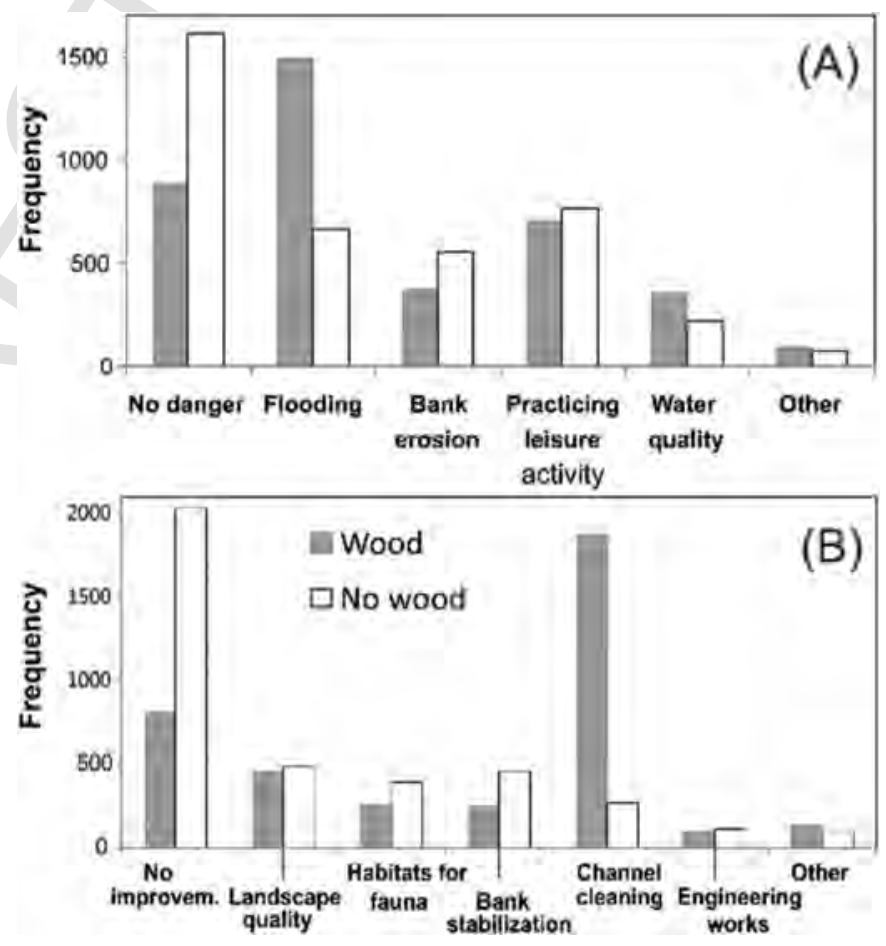

Fig. 6. Frequency distribution of (A) perceived types of danger and (B) improvement measurements needed for all surveys and pictures with and without wood.

applied the LCCA to all respondents (i.e., scientists and the general public). The results of the LCCA revealed four clusters (Table S2).

Among all the parameters analysed, the most relevant covariates to define the clusters were the place where the survey was done, the 
frequency of visits to rivers, the reasons for visiting, and the educational background. Other covariates such as gender, age, or living in a rural or urbanized area were not significant (Table S8).

The profiles of the four clusters are shown in Table 4 and can be summarized as follows:

- Cluster 1 - Environmental defender (39\% of respondents): This cluster perceived riverscapes without wood more dangerous than riverscapes with wood, and in general they perceived in a similar way riverscapes with and without wood in terms of aesthetics, naturalness, and with needs for improvements. This cluster is formed by scientists (32\%), respondents from Talavera de la Reina (14\%), Benasque (14\%), Castiello (13\%), and Vielha (10\%). A large part of the respondents $(46 \%)$ said that they visit rivers very frequently and the main reason for visiting was leisure $(85 \%)$. Most of them had undergraduate degrees $(45 \%)$, whereas $21 \%$ had postgraduate studies in natural sciences or engineering $(16 \%)$.

- Cluster 2 - Wood defender (27\%): This cluster is mainly composed by scientists (persons who filled the survey online, 74\%) who perceived riverscapes with wood as being more aesthetical and natural than rivers without wood. Respondents in this cluster said they visit rivers very frequently ( $>20$ times a year; $60 \%$ ), for leisure $(62 \%)$ and professional reasons $(38 \%)$, and most $(71 \%)$ of them had postgraduate degrees either in natural sciences or engineering.

- Cluster 3 - Wood fighter (26\%): Respondents who perceived scenes with wood as more dangerous, with a need for improvement, and scenes without wood as more aesthetically pleasant and natural. This group is formed mainly by respondents from Navaluenga (16\%), Arenas de San Pedro (18\%), Pradilla (16\%), and Sabiñánigo (11\%). Some $51 \%$ of the respondents from this cluster were from sites that have not been affected by recent floods (except for Pradilla where a flood occurred in 2013). Most of the respondents $(60 \%)$ said they visit fluvial systems $>20$ times per year, mainly for leisure $(92 \%)$. In this cluster, $74 \%$ of the respondents did not have a university degree.

- Cluster 4 - Riverscape contemplator (9\%): Formed by a very small percentage of respondents, the persons in this cluster perceived rivers without wood as more dangerous (mainly referred to picture Q) and with a need for improvement (referring mainly to pictures B, $\mathrm{F}$, and $\mathrm{N}$ ). Besides the presence of wood, in this cluster, respondents may have paid attention to other aspects, such as the turbulence of the water, the absence of vegetation or the channelization of rivers. They mostly (92\%) came from Navaluenga (55\%), Arenas de San Pedro $(26 \%)$, and Sabiñánigo $(10 \%)$, i.e. from localities that have not been affected by recent floods. Respondents from this cluster said they visit fluvial systems very often for leisure, and 59\% did not have a university degree.

Attitudes towards danger and improvements were related to different clusters (Table S9). Persons belonging to Clusters 1 and 3 were generally suggesting channel cleaning and engineering works in riverscapes with wood (63\%) and no improvements to riverscapes without wood (47\%). Respondents from Clusters 2 (mainly scientists) did not perceive the need for improvements in most riverscapes with $(51 \%)$ and without wood (64\%). Respondents from cluster 4 perceived riverscapes with and without wood with need for improvements regarding aesthetics and flooding (cleaning).

We also found a statistically significant (Pearson Chi-Square $p$-value $<0.05)$ association between the perception of riverscapes with and without wood for respondents from the four clusters and their opinion regarding management (Table 5).

As can be seen from Table 5, respondents from Cluster 2 disagreed more often $(43 \%)$ that river management would reduce flood risk whereas respondents from Clusters 3 and 4 totally agreed (94\% and $91 \%$, respectively) with this opinion. Regarding river clearance and bank stabilization as a river management strategy, most respondents from Clusters 3 and 4 (96\% and 94\%, respectively) agreed and most from Cluster $2(52 \%)$ disagreed. Most respondents from all the clusters agreed that river management should focus on landscape and ecosystem enhancement. Finally, the opinion that one should leave nature without river interventions was supported mainly by respondents from Clusters 1 and 2.

\section{Discussion and conclusions}

\subsection{Methodological aspects}

We used a photo-questionnaire that has already been tested in six studies to analyse the perception towards instream wood of people living in areas that have been affected more or less recently by floods, and to contrast results with the opinion from a group of scientists. The design of the survey in terms of the selection of pictures (Daniel and Boster, 1976; Bosselmann and Craik 1989) or the definition of the questions (including the definition of aesthetics, naturalness, danger or need for improvement) is not discussed here, and we refer to Piégay et al. (2005) and Le Lay et al. (2012) for considerations regarding study design. By contrast, some methodological aspects need to be discussed. The first aspect is about our target population and sample size, as they both determine the quantity and quality of the information gathered (Scheaffer et al., 2012). We carefully defined the population to be sampled to be able to test our initial hypothesis. To this end, we visited villages that have been affected recently by floods and villages that were not affected by floods over the last decades. The questionnaire was then distributed among adults and permanent residents. At these sites, we made sure to gather at least 28 fully completed surveys, which can be considered as a large-enough number to evaluate perception (i.e. between 25 and 30 according to Stamps, 1990).

In our case, the most important drawbacks are associated to the no observation type (Groves, 1989) and among these, probably the most serious is the nonresponse. In total, 388 respondents finished the survey satisfactorily, but many questionnaires were returned incomplete, especially in the online survey. Our nonresponse rate was very high, but this should not influence the final quality of our data, as data from a survey with a high nonresponse rate could still be informative if the no respondents looked like the respondents in all important characteristics (Scheaffer et al., 2012). In the field survey, the nonresponse was often related to the inability to contact a person or household, and in some cases in the inability of a person responding to come up with the answer to the question of interest, or refusal to answer. The inability of the interviewed person to answer the question, especially a question on opinion, can be solved adding a "don't know" option, thus the survey design can account for a certain percentage being in this category (Groves et al., 2002; Scheaffer et al., 2012). This has not been done in this study but should be considered in future surveys. However, the most frequent case, particularly in the online survey, was refusal to answer due to the length of the questionnaire. According to the demographic profile of respondents within the online group (Fig. S6) we observed that most of them were men (64\%), with an age ranging between 30 and 46 years (64\%) and postgraduates in Earth Sciences (53\%). This may reflect that a majority of the responses were given by academics and nonresponses corresponded to students (a category that was almost not represented in this group), who started the questionnaire but withdraw without filling all the questions. This could be related to the survey type, online self-admin- 
Table 4

Profiles of the four different clusters of respondents identified. C1-C4: Cluster 1 to 4. Grey marks the most relevant features in each cluster. 


\begin{tabular}{|c|c|c|c|c|c|}
\hline & \multirow{2}{*}{ Cluster } & \multicolumn{2}{|c|}{ Cluster 2 Cluster 3} & Cluster 4 & \multirow[b]{2}{*}{$\begin{array}{c}\text { Total } \\
(\mathrm{N}=388)\end{array}$} \\
\hline & & $\frac{\sqrt[3]{\frac{3}{2}}}{\frac{3}{3}}$ & $\frac{5}{3}$ & 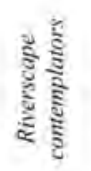 & \\
\hline Cluster size & 38.7 & 26.9 & 25.6 & 8.8 & \\
\hline Indicators (M) & & & & & \\
\hline Aesthetics of the riverscapes WTTH wood & 5.605 & 7920 & 5.006 & $1.96 t$ & 5.756 \\
\hline Naturalness of the riverscapes WITHl wood & 7,040 & 8.485 & 7,931 & 3.414 & 7339 \\
\hline Danger of the riverscapes WITH wood & 5.651 & 2,817 & 6.535 & 5.050 & 5.061 \\
\hline Need for improvement of the riverseapes WITH wood & 5.986 & 2.297 & 7.510 & 7.267 & 5.494 \\
\hline Aesthetics of the riverscapes WITHOUT wood & 6.262 & 7.286 & 7.900 & 5.505 & 6.891 \\
\hline Naturalness of the riverscapes WITHOUT wood & 6.310 & 6.884 & 7.815 & 5.888 & 6.812 \\
\hline Danger of the riverseapes WITHOUT wood & 4,577 & 3.029 & 3.933 & 4.413 & 3.981 \\
\hline Need for improvement of the riverscapes WITHOUT wood & 3.762 & 2.284 & 3.294 & 5,043 & 3.356 \\
\hline \multicolumn{6}{|l|}{ Covariates $(\%)$} \\
\hline \multicolumn{6}{|l|}{ Survey site } \\
\hline Internet & 32,1 & 74,0 & 7.4 & 6.0 & 34.8 \\
\hline Navaluenga (Central Spain, no recent floods) & 3.6 & 4.6 & 16.4 & 54.7 & 11.6 \\
\hline Vielha (Pyrenees, recent floods) & 9.8 & 4.3 & 10.0 & 0.0 & 7.5 \\
\hline Benasque (Pyrenees, recent floods) & 13.8 & 1.2 & 8.0 & 0.0 & 7.7 \\
\hline Castiello (Pyrenees, recent floods) & 12.6 & 3.0 & 8.0 & 0.0 & 7.7 \\
\hline Pradilla de Ebro (near Pyrenees, recent floods) & 7,6 & 2.9 & 15.8 & 0,0 & 7.7 \\
\hline Sabiñánigo (Pyrences, recent floods) & 5.6 & 7.2 & 10.7 & 10.2 & 7.7 \\
\hline Arenas de San Pedro (Central Spain, no recent fioods) & 1.0 & 2.9 & 17.7 & 26.4 & 8.0 \\
\hline Talavera de la Reina (Central Spain, no recent floods) & 14.1 & 0.0 & 6.0 & 2.6 & 7.2 \\
\hline \multicolumn{6}{|l|}{ Frequency of visit } \\
\hline Less than once a year & 5,2 & 2.6 & 96 & 5.9 & 5,7 \\
\hline Once- 5 times a year & 25.1 & 18.9 & 17.7 & 29,3 & 21.9 \\
\hline 6-20 times a year & 23.8 & 18.7 & 12.4 & 13.0 & 18.6 \\
\hline More than 20 times a yeat & 46,0 & 59.8 & 60.3 & 51.8 & 53,9 \\
\hline \multicolumn{6}{|l|}{ Reason for visit } \\
\hline Professional & 14.8 & 37.9 & 8.2 & 0.0 & 18,0 \\
\hline Leisure & 85.2 & 62.1 & 948 & 1000 & 82,0 \\
\hline \multicolumn{6}{|l|}{ Studies } \\
\hline Under graduate & 45.1 & 18.2 & 73.8 & 58.6 & 46.4 \\
\hline Postgraduate in Sciences & 21.3 & 43.8 & 2.3 & 0.0 & 20.6 \\
\hline Postgraduate in Engineering & 16.4 & 27.3 & 10.0 & 11.7 & 17.3 \\
\hline Other postgraduate studies & 17.2 & 10.7 & 13.9 & 29.8 & 15.7 \\
\hline
\end{tabular}


Table 5

Differences in the opinion regarding river/stream management between clusters. C1-C4: Cluster 1 to 4 . Grey marks the significant values.

\begin{tabular}{|c|c|c|c|c|c|c|c|c|}
\hline \multicolumn{2}{|c|}{$\begin{array}{c}\text { Opinion regarding river/stream } \\
\text { management }\end{array}$} & \multirow{2}{*}{ 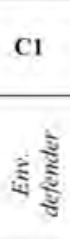 } & \multirow{2}{*}{ 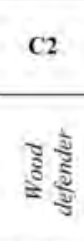 } & \multirow{2}{*}{ 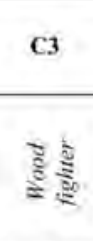 } & \multirow{2}{*}{ 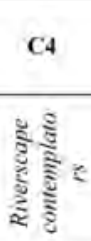 } & \multirow[t]{2}{*}{ Total } & \multicolumn{2}{|c|}{$\begin{array}{l}\text { Pearson Chi-Square } \\
\text { Value (df } \\
=3 \text { ) }\end{array}$} \\
\hline & & & & & & & & \\
\hline \multirow[b]{2}{*}{$\begin{array}{l}\text { Interventions reduce } \\
\text { flood risk }\end{array}$} & Agree (\%) & 82.5 & 57,1 & 93.7 & 91.2 & 79.1 & \multirow[t]{2}{*}{46.938} & \multirow[t]{2}{*}{$<0.001$} \\
\hline & Disagree $(\%)$ & 17.5 & 42,9 & 6.3 & 8.8 & 20.9 & & \\
\hline \multirow{2}{*}{$\begin{array}{l}\text { Should be focused on } \\
\text { streambed clearance and } \\
\text { bank stabilization }\end{array}$} & Agree (\%) & 77.3 & 47,6 & 95.8 & 94.1 & 75.3 & \multirow[t]{2}{*}{71.414} & \multirow[t]{2}{*}{$<0.001$} \\
\hline & Disagree (\%) & 22.7 & 52.4 & 4,2 & 5.9 & 24.7 & & \\
\hline \multirow{2}{*}{$\begin{array}{l}\text { Should be focused on } \\
\text { landscape and } \\
\text { ecosystem enthancement }\end{array}$} & Agree (\%) & 88.3 & 88.6 & 77.9 & 88.2 & 85.8 & \multirow[t]{2}{*}{6.507} & \multirow[t]{2}{*}{0.089} \\
\hline & Disagree $(\%)$ & 11.7 & 11,4 & 22.1 & 11.8 & 14.2 & & \\
\hline \multirow{2}{*}{$\begin{array}{l}\text { We should leave the } \\
\text { nature do wibhout river } \\
\text { interventions }\end{array}$} & Agree (\%) & 37.7 & 53.3 & 23.2 & 17.6 & 36.6 & \multirow{2}{*}{25,407} & \multirow{2}{*}{$<0.001$} \\
\hline & Disagree (\%) & 62.3 & 46,7 & 76.8 & 82.4 & 63.4 & & \\
\hline
\end{tabular}

istered questionnaire, as these surveys usually show a lower response rate (Scheaffer et al., 2012). One possible solution for encouraging responses in future surveys could be to offer a reward or incentive (non-economic) for responding, as people are more likely to respond to a survey if they see some potential benefit coming from the results (Scheaffer et al., 2012).

Regarding the two approaches used in our surveys (online and in person), results of the responses highlighted that no significant differences exist on the scores of riverscapes without wood and irrespective of whether the group was surveyed online or in person. Responses about riverscapes with wood were more variable in all cases. On-site studies may be considered to have a higher content validity (Roth, 2006), but the practical effort involved in such a work is also considerable (Roth and Gruehn, 2005). Therefore, we confirm that if the survey is properly targeted, internet surveys can be an objective and reliable instrument to gather valid data on landscape perception (Roth, 2006), although the high nonresponse rate should be taken into account.

As we surveyed people from different social groups, different regions, with different educational background and age, we disentangled the social aspects behind perception, classifying all the respondents in clusters (formed by respondents from all surveyed groups). To do this assessment, LCCA represents a powerful tool to decipher the different social aspects influencing wood perception in rivers. Moreover, LCCA allowed us to improve/characterize groups according to a set of opinions allowing highlighting their attitude towards wood and river management.

\subsection{Flooding impact on perception towards wood}

We found some differences in the scores given to river scenes with and without wood by respondents living in areas that were recently affected by floods and respondents from areas that have not experienced recent floods, especially in terms of perception of danger. However, results did not confirm our initial hypothesis that the generally negative perception of LW in rivers is enhanced among respondents living in places that have recently been affected by floods in terms of aesthetics, naturalness, or the need for improvements.
Interestingly, differences were found among respondents from the Pyrenees and Northern Spain and from those located in Central Spain. Therefore, recent flood experience is not the main factor controlling instream wood perception; instead, the influence of education, experience or information on the awareness of the geomorphic and ecological significance of wood in streams are significant variables as well (Mutz et al., 2006; Wyzga et al., 2009; Chin et al., 2014). Le Lay et al. (2008) found significant differences in perception towards wood in rivers using the same questionnaire to interview 250 students in ten different countries. They argued that differences were related to differences in cultural and land-use context, as well as in the familiarity with wood and rivers. We observe that even within the same country, regional differences can indeed exist, a finding that is in agreement with observations made by Chin et al. (2008) in different states in United States. One explanation could be related to the larger number of protected areas in the Pyrenees and Northern Spain as compared to Central Spain (EUROPARC, 2009). Respondents living near the Pyrenees and in Pradilla might be more accustomed to better preserved and more natural rivers, and they value natural areas for leisure activities; whereas in Central Spain agriculture and grazing have replaced large forested areas. Further studies are needed to better understand these regional aspects.

We also find significant differences between scientists and the general public. Surveyed scientists perceived riverscapes with wood as more aesthetically pleasant, less dangerous and needing less improvement than respondents from general public. Thus, we confirmed the existence of a gap between scientific and general public perception of natural river systems with wood. The difference between experts and non-experts preferences regarding landscape in general was already observed by Kaplan and Kaplan (1989) and Chin et al. (2012) also observed differences in LW in rivers perception between river managers and non-experts (represented by undergraduate students). This confirms the effort to promote and emphasize the positive ecological and geomorphic role of LW and to draw attention to negative consequences of its extraction. However, further efforts in training and education are still required to bridge the gap between scientists and the general public. As pointed out by Chin et al. (2008), it is essential that scientists translate research findings effectively to the general public, managers, and policy-makers, emphasizing the posi- 
tive aspects of wood. This would help foster acceptance of river management policies (e.g., restoration projects including wood augmentation) formulated based on results of scientific research (Chin et al., 2008).

By contrast, in many cases, we did not find statistically significant differences between the scores given by scientists to scenes with and without wood. This unexpected result may be explained by the background of scientists. The profile of respondents (Fig. S6) was majorly researchers (e.g., $\mathrm{PhD}$ students and postdocs) and professors, and not students. Therefore, the expected familiarity with river systems and river ecology and risk understanding, although from slightly different perspectives (i.e., geosciences and engineering), would explain the perception of the riverscapes. The results of the LCCA allowed us to better disentangle this large group (see Supplementary material and Section 3.2).

\subsection{River management implications}

Nowadays the loss of LW has been shown to alter channel form and processes, thus contributing to greater sediment fluxes, more rapid bank erosion and incision, and thus to a loss of heterogeneity in bed morphology (Booth et al., 1997; Wohl, 2016). The negative perception of LW may cause very common and socially appreciated wood removal actions. Spanish landowners and territorial actors constantly request the 'cleaning of streambeds' to public authorities, both for flood control or road maintenance purposes. This clearing is very often non-selective, and usually includes living vegetation removal from the riparian corridor and the dredging of sediment from river channels (Ollero, 2013). These activities are considered (and funded) as 'emergency post-flood works' to increase channel capacity and to "alleviate people" (Serrano-Notivoli et al., 2015). However, these actions are usually just undertaken at the very local scale and without any environmental protocol, therefore causing very important disturbances on river form and processes, deteriorating ecological quality, and accelerating incision processes. Moreover, the most advanced hydromorphological assessments at the European level evaluate these removal actions as very negative (Ollero et al., 2011; Rinaldi et al., 2013). This study underlines that respondents from sites recently affected by floods do not show more severe or negative attitude towards wood in rivers, demonstrating that wood removal should be more balanced in emergency post-flood works and public information is really needed to implement balanced instream wood management policy. Therefore, current practices should be reconsidered in Spain. Some steps have been undertaken in this direction, and only recently, Water Authorities have been obliged to survey LW in river channels and to manage this aspect of the stream habitat (Ortega-Terol et al., 2014). Other strategies may be considered to conserve LW in channels (e.g., Wohl et al., 2016; Mazzorana et al., 2017), such as the installation of retention structures upstream of critical sections or sensitive areas (Piton and Recking, 2015) or by modifying existing infrastructure (i.e., bridges, culverts, and fords) to allow LW passage (Lassettre and Kondolf, 2012). Guidelines exist in other countries (e.g. Sabo Department, Ministry of Construction, Japan, 2000; Mao et al., 2013), notably in France (Piégay and Landon, 1997; Boyer et al., 1998), to highlight pros and cons of large wood in rivers and to recommend a sectorised approach of LW management according to the objectives discussed so as to leave, remove or also reintroduce wood accordingly (Mazzorana et al., 2017; Wohl et al., 2016).

Perception surveys, like the one presented here, can complement technical work in the context of river management, and notably river restoration, in which the question of how we would like a landscape to be is critical (Junker and Buchecker, 2008; Ashmore, 2015). In case that people consider that wood is not aesthetic or even dangerous; these perceptions could have important consequences on the implementation of management measures. Over the last few decades, forest cover has generally increased in Spain because of the widespread abandonment of agricultural fields and changes in farming practices. Therefore, one may expect that wood recruitment to rivers will increase at some stage (Ollero, 2014), as it is already observed in other regions of Europe (Lassettre et al., 2008). Therefore, river managers will need to deal with LW more often in the near future, and so clear management strategies will be required.

\section{Uncited reference}

Wohl et al., 2010

\section{Acknowledgments}

Authors thank all the interview participants, and collaborators who distributed the online survey among colleagues and students. Special thanks go to Elisabet Peñuela, Gonzalo Peño, Ignacio Ibáñez, Diego López, and Sergio Santolaria (University of Zaragoza, Spain), Dany Caetano (Universidad Federal de Santa Catarina, Brasil), and M. Angeles Perucha (Geological Survey of Spain) for their collaboration in the field surveys.

This work has been partially supported by the projects MAS Dendro-Avenidas (CGL2010-19274) and MARCoNI (CGL2013-42728-R) and Dendrolab.ch (University of Bern, Switzerland) and the WoodFlow project funded by the Swiss Federal Office for the Environment (FOEN). Comments from three anonymous reviewers significantly improved the manuscript.

\section{Appendix A. Supplementary data}

Supplementary data to this article can be found online at https:// doi.org/10.1016/j.scitotenv.2018.04.096.

\section{References}

Ashmore, P., 2015. Towards a sociogeomorphology of rivers. Geomorphology 251, https://doi.org/10.1016/j.geomorph.2015.02.020.

Bechtel, A., Churchman, R.B., 2002. Handbook of Environmental Psychology. Wiley, New York.

Benke, A.C., Wallace, J.B., 2003. Influence of wood on invertebrate communities in streams and rivers. Ecology and management of wood in world rivers. Am. Fish. Soc. Symp. 37, 149-177.

Bodoque, J.M., Amérigo, M., Díez-Herrero, A., García, J.A., Cortés, B., Ballesteros-Cánovas, J.A., Olcina, J., 2016. Improvement of resilience of urban areas by integrating social perception in flash-flood risk management. J. Hydrol. 541, 665-676. https://doi.org/10.1016/j.jhydrol.2016.02.005.

Booth, D.B., Montgomery, D.R., Bethel, J., 1997. Large woody debris in urban streams of the Pacific Northwest. In: Roesner, L.A. (Ed.), Effects of Watershed Development and Management on Aquatic Ecosystems. Engineering Foundation Conference, Proceedings, Snowbird, Utah, pp. 178-197.

Boyer, M., Piégay, H., Ruffinoni, C., Citterio, A., Bourgery, C., Caillebote, P., 1998. Guide technique SDAGE - La gestion des boisements de rivière. Agence de l'Eau Rhône Méditerranée Corse, 2 Volumes, 49 p et 56 p + Annexes. In: https:// siecorse.eaurmc.fr/gestion-eau/archives/documents/guide-tech-1-f1.pdf.

Brooks, A.P., Abbe, T.B., Jansen, J.D., Taylor, M., Gippel, C.J., 2001. Putting the wood back into our rivers: an experiment in river rehabilitation. In: Rutherfurd, I., Sheldon, F., Brierley, G., Kenyon, C. (Eds.), Proceedings of the 3rd Australian Stream Management Conference, Brisbane, Australia. pp. 73-80.

Brown, T.C., Daniel, T.C., 1984. Modelling Ponderosa Pine Scenic Beauty. In: USDA Forest Service Research Paper RM-256. U.S. Forest Service, Washington, D.C..

Carlson, A.A., 1977. On the possibility of quantifying scenic beauty. Landsc. Plann. 4, $131-172$.

Chin, A., Daniels, M.D., Urban, M.A., Piégay, H., Gregory, K.J., Bigler, W., Butt, A.Z., Grable, J.L., Gregory, S.V., Lafrenz, M., Laurencio, L.R., Wohl, E., 2008. 
Perceptions of wood in rivers and challenges for stream restoration in the United States. Environ. Manag. 41, 893-903.

Chin, A., Laurencio, L.R., Daniels, M.D., Wohl, E., Urban, M.A., Boyer, K.L., Butt, A., Piégay, H., Gregory, K.J., 2014. The significance of perceptions and feedbacks for effectively managing wood in rivers. River Res. Appl. 30, 98-111.

Comiti, F., 2012. How natural are Alpine mountain rivers? Evidence from the Italian Alps. Earth Surf. Process. Landf. 37, 693-707.

Comiti, F., Agostino, V.D., Moser, M., Lenzi, M.A., Bettella, F., Agnese, A.D., Mazzorana, B., 2012. Preventing wood-related hazards in mountain basins, from wood load estimation to designing retention structures. In: Interpraevent $12^{\text {th }}$ Congress Proceedings, Grenoble, France.

Comiti, F., Lucía, A., Rickenmann, D., 2016. Large wood recruitment and transport during large floods: a review. Geomorphology 23-39. https://doi.org/10.1016/j. geomorph.2016.06.016

Correa, L., 2013. ¿Para qué SÍ hay que limpiar los ríos?. Available at: http://www iagua.es/blogs/lorenzo-correa/\%C2\%BFpara-que-si-hay-que-limpiar-los-rios.

Daniel, T.C., Boster, R.S., 1976. Measuring landscape aesthetics: the scenic beauty estimation method. In: USDA Forest Service Research Paper RM-167. U.S. Forest Service, Washington, D.C..

Diehl, T.H., 1997. Potential Drift Accumulation at Bridges. US Department of Transportation, Federal Highway Administration Research and Development, McLean, Virginia, USA.

Díez-Herrero, A., Amerigo, M., Bodoque, J.M., García, J.A., Olcina-Cantos, J., 2015. Integration of Social Perception in Flash Flood Risk Management for Resilience Improvement. Abstract European Geosciences Union, Vienna, Austria.

EUROPARC, 2009. Anuario del estado de los espacios naturales protegidos. 2009 http://www.redeuroparc.org/system/files/shared/Anuario2009.pdf.

Gregory, S., Boyer, K.L., Gurnell, A.M., 2003. The ecology and management of wood in world rivers. Am. Fish. Soc. Symp. 37

Groves, R.M., 1989. Survey Errors and Survey Costs. Wiley, New York.

Groves, R., Dillman, D., Eltinge, J., Little, R. (Eds.), 2002. Survey Nonresponse. Wiley, New York.

Gurnell, A.M., 2012. Fluvial geomorphology: wood and river landscapes. Nat. Geosci. $5,93-94$.

Gurnell, A.M., Surian, N., Zanoni, L., 2009. Multi-thread river channels: a perspective on changing European alpine river systems. Aquat. Sci. 71, 253-265.

Higgs, E.S., 1997. What is good ecological restoration?. Conserv. Biol. 11, 338-348.

Junker, B., Buchecker, M., 2008. Aesthetic preferences versus ecological objectives in river restorations. Landsc. Urban Plan. 85, 141-154.

Kail, J., Hering, D., Muhar, S., Gerhard, M., Preis, S., 2007. The use of large wood in stream restoration: experiences from 50 projects in Germany and Austria. J. Appl. Ecol. 44, 1145-1155.

Kaplan, R., Kaplan, S., 1989. The Experience of Nature. A Psychological Perspective. Cambridge University Press, Cambridge.

Kaufman, L., Rousseeuw, P.J., 1990. Finding Groups in Data. John Wiley and Sons, New York.

Lassettre, N.S., Kondolf, G.M., 2012. Large woody debris in urban stream channels: redefining the problem. River Res. Appl. 28, 1477-1487.

Lassettre, N.S., Piégay, H., Dufour, S., Rollet, A.J., 2008. Decadal changes in distribution and frequency of wood in a free meandering river, the Ain River, France. Earth Surf. Process. Landf. 33, 1098-1112.

Le Lay, Y.F., Piégay, H., Gregory, K., Chin, A., Dolédec, S., Elosegi, A., Mutz, M., Wyżga, B., Zawiejska, J., 2008. Variations in cross-cultural perception of riverscapes in relation to in-channel wood. Trans. Inst. Br. Geogr. 33, 268-287.

Le Lay, Y.F., Cottet, M., Piégay, H., Riviere-Honegger, A., 2012. Ground imagery and environmental perception. In: Carbonneau, P.E., Piégay, H. (Eds.), Fluvial Remote Sensing for Science and Management. John Wiley and Sons, pp. 405-430.

Le Lay, Y.F., Piégay, H., Moulin, B., Shroder, 2013. Wood entrance, deposition, transfer and effects on fluvial forms and processes: problem statements and challenging issues. In: Treatise on Geomorphology. Elsevier.

Liébault, F., Piégay, H., 2002. Causes of 20th century channel narrowing in mountain and piedmont rivers of Southeastern France. Earth Surf. Process. Landf. 27, $425-444$.

Lucía, A., Comiti, F., Borga, M., Cavalli, M., Marchi, L., 2015. Dynamics of large wood during a flash flood in two mountain catchments. Nat. Hazards Earth Syst. Sci. 3, 1643-1680.

Lyn, D., Cooper, T., Condon, D., Gan, L., 2007. Factors in Debris Accumulation at Bridge Piers. Washington, U.S. Department of Transportation, Federal Highway Administration Research and Development, Turner-Fairbank Highway Research Center.

Mao, L., Comiti, F., 2010. The effects of large wood elements during an extreme flood in a small tropical basin of Costa Rica. In: De Wrachien, D., Brebbia, C.A. (Eds.), Debris Flow III. WIT Press, UK, pp. 225-236.

Mao, L., Andreoli, A., Iroumé, A., Comiti, F., Lenzi, M., 2013. Dynamics and management alternatives of in-channel large wood in mountain basins of the southern Andes. Bosque 34, 319-330.
Mazzorana, B., et al., 2017. Assessing and mitigating large wood-related hazards in mountain streams: recent approaches. J. Flood Risk Manag. https://doi.org/10. $1111 / \mathrm{jfr} 3.12316$

Miller, J.R., Hobbs, R.J., 2007. Habitat restoration: do we know what we are doing?. Restor. Ecol. 15, 382-390.

Mutz, M., Piégay, H., Gregory, K.J., Borchardt, D., Reich, M., Schnieder, K., 2006. Perception and evaluation of dead wood in streams and rivers by German students. Limnologica 36, 110-118.

Nagayama, S., Nakamura, F., Kawaguchi, Y., Nakano, D., 2012. Effects of configuration of instream wood on autumn and winter habitat use by fish in a large remeandering reach. Hydrobiologia 680, 159-170.

Ollero, A., 2013. ¿Por qué NO hay que limpiar los ríos?. Available at: http://riverkeeper.blogspot.ch/2013/01/por-que-no-hay-que-limpiar-los-rios.html.

Ollero, A., 2014. Guía metodológica sobre buenas prácticas en gestión de inundaciones. Manual para gestores. Contrato del río Matarraña, ECODES, Zaragoza, (143 pp.).

Ollero, A., Ibisate, A., Gonzalo, L.E., Acín, V., Ballarín, D., Díaz, E., Domenech, S., Gimeno, M., Granado, D., Horacio, J., Mora, D., Sánchez Fabre, M., 2011. The IHG index for hydromorphological quality assessment of rivers and streams: updated version. Limnetica 30, 255-262.

Ortega-Terol, D., Moreno, M.A., Hernández López, D., Rodríguez Gonzálvez, P., 2014. Survey and classification of large woody debris (LWD) in streams using generated low-cost geomatic products. Remote Sens. 6, 11770-11790.

Palmer, J.F., 2008. The perceived scenic effects of clearcutting in the White Mountains of New Hampshire, USA. J. Environ. Manag. 89, 167-183.

Piégay, H., Landon, N., 1997. Promoting ecological management of riparian forests on the Drome river, France. Aquat. Conserv. Mar. Freshwat. Ecosyst. 7, 287-304.

Piégay, H., Gregory, K.J., Bondarev, V., Chin, A., Dahlstrom, N., Elosegi, A., Gregory, S.V., Joshi, V., Mutz, M., Rinaldi, M., Wyzga, B., Zawiejska, J., 2005. Public perception as a barrier to introducing wood in rivers for restoration purposes. Environ. Manag. 36, 665-674.

Piton, G., Recking, A., 2015. Design of sediment traps with open check dams. II: Woody debris. J. Hydraul. Eng. https://doi.org/10.1061/(ASCE)HY.1943-7900. 0001049.

Reich, M., Kershner, J.L., Wildman, R.C., 2003. Restoring streams with large wood: a synthesis. In: Gregory, S., Boyer, K., Gurnell, A.M. (Eds.), The Ecology and Management of Wood in World Rivers. American Fisheries Society, Bethesda, pp. $355-366$.

Ribe, R.G., 2006. Perceptions of forestry alternatives in the US Pacific Northwest: information effects and acceptability distribution analysis. J. Environ. Psychol. 26, $100-115$.

Ribe, R.G., 2009. In-stand scenic beauty of variable retention harvests and mature forests in the U.S. Pacific Northwest: the effects of basal area, density, retention pattern and down wood. J. Environ. Manag. 91, 245-260.

Rinaldi, M., Surian, N., Comiti, F., Bussettini, M., 2013. A method for the assessment and analysis of the hydromorphological condition of Italian streams: the Morphological Quality Index (MQI). Geomorphology 180-181, 96-108.

Roni, P., Beechie, T., 2013. Stream and Watershed Restoration: A Guide to Restoring Riverine Processes and Habitats. Wiley-Blackwell, Chichester, England.

Rosenberger, R.S., Smith, E.L., 1998. Assessing Forest Scenic Beauty Impacts of Insects and Management. Forest Health and Technology Enterprise Team Report 98-08 USDA Forest Service, Fort Collins, CO.

Roth, M., 2006. Validating the use of internet survey techniques in visual landscape assessment-an empirical study from Germany. Landsc. Urban Plan. 78, 179-192.

Roth, M., Gruehn, D., 2005. Scenic Quality Modelling in Real and Virtual Environments. In: Buhmann, E., Paar, P., Bishop, I.D., Lange, E. (Eds.), Trends in Real-time Visualization and Participation. Wichmann Verlag, Heidelberg, pp. 291-302.

Ruiz-Villanueva, V., Bodoque, J.M., Díez-Herrero, a., Bladé, E., 2014. Large wood transport as significant influence on flood risk in a mountain village. Nat. Hazards 74, 967-987. https://doi.org/10.1007/s11069-014-1222-4.

Ruiz-Villanueva, V., Piégay, H., Gurnell, A.A., Marston, R.A., Stoffel, M., 2016. Recent advances quantifying the large wood dynamics in river basins: new methods and remaining challenges. Rev. Geophys. 54, https://doi.org/10.1002/ 2015RG000514

Rutherfurd, I.D., Marsh, N., Price, P., Lovett, S., 2002. Managing woody debris in rivers. Land and Water Australia 7, 16

Sabo Department, Ministry of Construction, Japan, 2000. Guideline for driftwood countermeasures. In: Guideline of Ministry of Construction, Japan. http://www sabo-int.org/guideline/pdf/driftwoodCountermeasureGuideline.pdf, (online accessed on 16 March 2018).

Scheaffer, R.L., Mendenhall III, W., Ott, L.R., Gerow, K.G., 2012. Survey Sampling (7th Intl Edn). Brooks/Cole - Cengage Learning, Stamford, CT.

Sedell, J.R., Steedman, R.J., Regier, H.A., Gregory, S., 1991. Restoration of human-impacted land-water ecotones. In: Holland, M.M., Risser, P.G., Naiman, R.J. (Eds.), Ecotones: The Role of Landscape Boundaries in the Management and Restoration of Changing Environments. Chapman \& Hall, New York, pp. 110-129. 
Serrano-Notivoli, R., Liesa, B., Mora, D., Ollero, A., Revuelto, C., Sánchez Fabre, M., Sanz, P., y Saz, M.A., 2015. Vulnerabilidad del territorio ante crecidas relámpago en el Pirineo Central: alternativas de gestión del riesgo. Actas del II Congreso Ibérico de Restauración Fluvial Restauraríos. 2015, 677-681, (Pamplona. Spain).

SIGPAC, 2014. Ministerio de Agricultura, Alimentación y Medio Ambiente. Sistema de Información Geográfica de Parcelas Agrícolas.

Stamps, A.E., 1990. Use of photographs to simulate environment: a meta-analysis. Percept. Mot. Skills 71, 907-913.

Steeb, N., Rickenmann, D., Badoux, A., Rickli, C., Waldner, P., 2017. Large wood recruitment processes and transported volumes in Swiss mountain streams during the extreme flood of August 2005. Geomorphology https://doi.org/10.1016/j. geomorph.2016.10.011.

Stokols, D., 1995. The paradox of environmental phsycology. Am. Psychol. 50, $821-837$.

Vermunt, J.K., 2003. Applications of latent class analysis in social science research. In: Symbolic and Quantitative Approaches to Reasoning with Uncertainty. Lecture Notes in Computer Science. 2711, pp. 22-36.

Vermunt, J.K., Magidson, J., 2002. Latent class cluster analysis. In: Hagenaars, J.A. McCutcheon, A.L. (Eds.), Advances in Latent Class Analysis. Cambridge University Press.

Vining, J., Tyler, E., Kweon, B.-S., 2000. Public values, opinions, and emotions in restoration controversies. In: Gobster, P.H., Hull, R.B. (Eds.), Restoring Nature. Perspectives from the Social Sciences and Humanities. Island Press, Washington D.C., pp. 143-161.

Wapner, S., Demick, J., 2002. The increasing contexts of context in the study of environment behavior relations. In: Bechtel, R.B., Churchman, A. (Eds.), Handbook of Environmental Psychology. pp. 3-14.
Wohl, E., 2013. Floodplains and wood. Earth-Sci. Rev. 123, 194-212.

Wohl, E., 2014. A legacy of absence: wood removal in US rivers. Prog. Phys. Geogr. $38,637-663$

Wohl, E., 2015. Of wood and rivers: bridging the perception gap. In: Wiley Interdisciplinary Reviews: Water. 2, pp. 167-176.

Wohl, E., 2016. Messy rivers are healthy rivers: the role of physical complexity in sustaining ecosystem processes. River Flow 2016, 24-29.

Wohl, E., 2017. Bridging the gaps: an overview of wood across time and space in diverse rivers. Geomorphology 279, 3-26. https://doi.org/10.1016/j.geomorph.2016. 04.014.

Wohl, E., Scott, D.N., 2016. Wood and sediment storage and dynamics in river corridors. Earth Surf. Process. Landf. https://doi.org/10.1002/esp.3909.

Wohl, E., Cenderelli, D.A., Dwire, K.A., Ryan-Burkett, S.E., Young, M.K., Fausch, K.D., 2010. Large in-stream wood studies: a call for common metrics. Earth Surf. Process. Landf. 35, 618-625.

Wohl, E., Bledsoe, B.P., Fausch, K.D., Kramer, N., Bestgen, K.R., Gooseff, M.N., 2016. Management of large wood in streams: an overview and proposed framework for hazard evaluation. Am. Water Resour. Assoc. 52, 315-335.

Wyzga, B., Zawiejska, J., Le Lay, Y.F., 2009. Influence of academic education on the perception of wood in watercourses. J. Environ. Manag. 90, 587-603.

Zube, E.H., Pitt, D.G., 1981. Cross-cultural perceptions of scenic and heritage landscapes. Landscape Planning 8, 69-87. 